\title{
Analisis Pengaruh Ukuran Kantor Akuntan Publik Terhadap Kualitas Audit di Indonesia
}

\author{
Chairunissa Nindita \& Sylvia Veronica Siregar \\ Universitas Indonesia \\ Email: sylvia.veronica@ui.ac.id
}

\begin{abstract}
ABSTRAK
Penelitian ini bertujuan untuk mengetahui pengaruh ukuran kantor akuntan publik, yang diukur melalui jumlah rekan, jumlah auditor, jumlah klien dan jumlah pendapatan kantor akuntan publik terhadap kualitas audit yang diukur dengan akrual diskresioner dan opini audit going concern. Sampel penelitian adalah perusahaan manufaktur yang terdaftar di Bursa Efek Indonesia tahun 2006-2008 dengan observasi sebanyak 348 perusahaan. Metode regresi berganda dan regresi logistik digunakan untuk menguji hipotesis. Hasil penelitian secara keseluruhan, untuk semua sampel maupun untuk sub sampel perusahaan yang diaudit KAP Big 4 dan sub sampel perusahaan yang diaudit KAP non Big 4, menunjukkan bahwa tidak terdapat pengaruh yang signifikan antara ukuran kantor akuntan publik dengan kualitas audit. Ukuran KAP yang besar tidak selalu menghasilkan kualitas audit yang tinggi. Kualitas audit KAP besar dan kecil dapat dianggap cukup seragam.
\end{abstract}

Kata kunci: Ukuran KAP, kualitas audit, akrual diskresioner, opini going concern.

\begin{abstract}
This study aims to examine the effect of public accounting firm size, measured by number of partners, number of auditor staffs, number of clients, and public accounting firm's revenue, on audit quality (measured by the accruals quality and going concern audit opinion). Samples are manufacturing firms listed in Indonesia Stock Exchange for the year 2006-2008 with total observations of 348 firm-years. Multiple regression and logistic regression is used for hypotheses testing. The results show that for the entire samples as well as for two sub samples, the sub-samples of firms audited by Big 4 and sub-samples of firms audited by Non-Big 4, there are no significant effect of public accounting firm size on audit quality. Large accounting firms does not always produce high quality audit. Thus, audit quality of large and small accounting firms can be considered fairly uniform.
\end{abstract}

Keywords: Size of public accounting firm, audit quality, discretionary accruals, going concern opinion.

\section{PENDAHULUAN}

DeAngelo (1981) menyatakan bahwa kualitas audit dari akuntan publik dapat dilihat dari ukuran KAP yang melakukan audit. KAP besar (Big 4 accounting firms) diyakini melakukan audit lebih berkualitas dibandingkan dengan KAP kecil (Non-Big 4 accounting firm). Namun pada tahun 2001, terjadi kasus financial statement fraud di Enron dan juga beberapa kasus lainnya. Dalam kasus-kasus tersebut akuntan publik yang mengaudit termasuk kantor akuntan publik yang berukuran besar dan memiliki reputasi yang baik.
Kasus-kasus tersebut menunjukkan bahwa tidak semua kantor akuntan publik yang berukuran besar melakukan audit yang berkualitas tinggi.

Kualitas audit akan berpengaruh pada laporan audit yang dikeluarkan auditor. Terdapat empat kategori laporan audit menurut Arens et al. (2009) yaitu wajar tanpa pengecualian, wajar tanpa pengecualian dengan paragraf penjelasan atau modifikasi kalimat, wajar dengan pengecualian dan tidak wajar atau menolak memberikan pendapat. Masing-masing dari laporan audit tersebut dikeluarkan dengan kondisi yang berbedabeda. Auditor dituntut untuk menggunakan kom- 
petensi dan independensinya semaksimal mungkin dalam melakukan proses audit agar menghasilkan opini yang sesuai karena reputasi auditor juga ikut dipertaruhkan ketika opini ternyata tidak sesuai dengan kondisi perusahaan yang sesungguhnya.

Laporan keuangan menjadi sumber informasi keuangan yang penting bagi investor dan kreditur. Salah satu unsur laporan keuangan yang sering diperhatikan adalah laporan laba rugi di mana informasi mengenai laba akan dilaporkan. Namun pelaporan laba tersebut belum tentu menunjukkan laba yang sesungguhnya, karena laba tersebut mungkin mengandung unsur akrual yang dapat menjadi risiko informasi akibat manajemen laba yang dilakukan perusahaan. Auditor dituntut untuk menilai kewajaran penyajian laba tersebut.

Banyaknya kasus terkait kesalahan auditor dalam menjalankan perannya, menyebabkan para pengguna laporan keuangan memiliki penilaian skeptis terhadap auditor. Salah satunya adalah pendapat bahwa kantor akuntan publik berukuran besar atau biasanya disebut dengan Big 4, tidak menjamin laporan keuangan yang diaudit tidak mengandung kesalahan yang material. Penilaian skeptis tersebut didukung dengan adanya penelitian Francis \& Yu (2009), yang memberikan bukti empiris ketidakseragaman kualitas audit pada kantor audit Big 4 di Amerika. Penelitian di atas merupakan kelanjutan dari penelitian sebelumnya yang dilakukan Francis et al. (1999) dan Ferguson et al. (2003). Namun, penelitian sebelumnya tersebut hampir tidak ada yang melakukan pengujian secara terpisah antara kelompok sampel yang merupakan klien KAP Big 4 dan kelompok sampel yang merupakan klien KAP Non-Big 4 agar dapat melihat keseragaman kualitas audit pada masing-masing kelompok sampel. Hal inilah yang membedakan penelitian ini dengan penelitian terdahulu, seperti Francis \& Yu (2009).

Hubungan antara ukuran kantor akuntan publik dengan kualitas audit sebenarnya sudah sering menjadi topik sejumlah studi empiris, seperti DeAngelo (1981), Choi et al. (2010), Pratiwi (2010) dan Pardede (2010). Hasil penelitian DeAngelo (1981) menunjukkan semakin besar ukuran kantor akuntan publik, semakin baik kualitas audit yang akan dihasilkan. Oleh karena itu, secara tidak langsung kantor akuntan publik Big 4, yang memiliki ukuran yang besar dianggap memiliki kualitas audit yang baik. Choi et al. (2010) juga menemukan ukuran KAP yang lebih besar akan menghasilkan kualitas audit yang lebih baik dibanding ukuran KAP yang lebih kecil.

Sedangkan penelitian Pratiwi (2010) dan Pardede (2010) mendapatkan hasil yang berbeda dari kedua penelitian di atas. Penelitian yang dilakukan di Indonesia ini menunjukkan bahwa ukuran KAP atau tipe KAP yang di lambangkan oleh Big 4 dan Non-Big 4 tidak mempunyai pengaruh dengan kualitas audit. Artinya KAP Big 4 belum tentu menghasilkan kualitas audit yang lebih baik daripada KAP Non-Big 4. Perbedaan hasil penelitian inilah yang menarik untuk diteliti lebih lanjut.

Selain perbedaan hasil penelitian tersebut, yang menarik lainnya untuk diteliti adalah apakah semua kantor akuntan publik Big 4 akan menghasilkan kualitas audit yang baik? Apakah semua kantor akuntan publik Non-Big 4 akan menghasilkan kualitas audit yang kurang baik? Menggunakan data yang terdapat pada pasar modal Amerika, Francis \& Yu (2009) telah melakukan penelitian guna menjawab pertanyaan tadi. Dari penelitian tersebut ditemukan adanya ketidakseragaman kualitas audit pada kantor akuntan publik Big 4. Namun, apakah hasil penelitian tersebut berlaku juga untuk KAP Big 4 di Indonesia dan bagaimana pula untuk KAP NonBig 4?

Berdasarkan latar belakang di atas, maka penelitian ini mencoba mengkaji pengaruh ukuran kantor akuntan publik terhadap kualitas audit, apakah dengan ukuran kantor akuntan publik yang lebih besar akan menghasilkan kualitas audit yang lebih baik dibanding kualitas audit yang dihasilkan dari kantor akuntan publik yang lebih kecil, dengan melakukan pengujian untuk semua sampel yang diaudit KAP besar dan kecil serta menguji untuk sub sampel perusahaan yang diaudit KAP besar (Big 4) dan yang diaudit KAP kecil (KAP Non Big 4).

\section{PENELITIAN TERDAHULU}

Penelitian yang menguji hubungan antara ukuran KAP dan kualitas audit sudah banyak dilakukan. Seperti DeAngelo (1981) yang mendapatkan hasil bahwa KAP besar (big 4 accounting firms) melakukan audit lebih berkualitas dibandingkan dengan KAP kecil (non big 4 accounting firms). Begitu juga dengan penelitian Choi et al. (2010) yang mendapatkan hasil yang serupa. Klien biasanya mempersepsikan bahwa auditor yang berasal dari KAP besar dan yang memiliki afiliasi dengan KAP internasional akan memiliki kualitas yang lebih tinggi. Hal ini disebabkan karena auditor tersebut memiliki karakteristik yang dapat dikaitkan dengan kualitas, seperti pelatihan dan juga pengakuan internasional. Namun dalam kenyataannya terdapat beberapa kasus yang menunjukkan sebaliknya. Salah satunya adalah kasus Enron yang membuktikan ukuran KAP 
yang besar belum tentu menghasilkan kualitas audit yang tinggi. Hal ini menyebabkan makin banyak penelitian-penelitian yang mencoba mengkaji kembali hubungan antara ukuran KAP dan kualitas audit dengan menggunakan berbagai macam ukuran baik untuk ukuran KAP maupun kualitas audit.

Herusetya (2009) menemukan bahwa reputasi auditor (yang diukur berdasarkan ukuran KAP) berhubungan positif dengan kualitas pelaporan keuangan, termasuk kualitas laba. Kualitas pelaporan keuangan disini dapat dianggap sebagai kualitas audit karena kemampuan menghasilkan pelaporan keuangan yang berkualitas bertujuan untuk melindungi reputasi nama KAP. Oleh karenanya ketika reputasi auditor baik seperti Big 4, auditor tersebut cenderung menghasilkan kualitas audit yang baik pula agar reputasi mereka tetap baik.

Selain itu, Novita (2009) terinspirasi dari Li et al. (2008) melakukan penelitian mengenai hubungan antara ukuran KAP dan kualitas audit dengan menggunakan sampel perusahaan manufaktur yang terdaftar di Bursa Efek Indonesia tahun 2005-2007. Penelitian ini menggunakan indikator fee auditor dan reputasi KAP sebagai variabel ukuran KAP. Sedangkan kualitas audit diukur dengan proksi opini auditor. Hasilnya kedua faktor tersebut tidak mempengaruhi opini audit. Pardede (2010) juga menemukan bahwa ukuran KAP tidak menjadi salah satu faktor yang mempengaruhi kualitas audit.

Penelitian terbaru yang dilakukan Francis \& Yu (2009), menemukan semakin besar ukuran KAP, kualitas audit yang dihasilkan akan semakin tinggi. Penelitian Choi et al. (2010) juga menemukan hasil yang konsisten. Penelitian tersebut menggunakan ukuran akrual diskresioner untuk kualitas audit dan untuk ukuran KAP menggunakan jumlah klien serta pendapatan audit.

Dari hubungan yang positif tersebut menandakan bahwa KAP berukuran besar menghasilkan kualitas audit yang lebih tinggi bila dibandingkan dengan KAP kecil. Oleh karena itu, walaupun pada kenyataannya terdapat kasuskasus yang memberikan gambaran bahwa tidak semua KAP besar akan menghasilkan kualitas audit yang tinggi namun penelitian-penelitian yang telah dilakukan sebagian besar menghasilkan hubungan yang positif antara ukuran KAP dan kualitas audit.

Francis \& Yu (2009) menggunakan total akrual diskresioner sebagai ukuran dari kualitas akrual yang dijadikan proksi dari kualitas audit. Akrual diskresioner mengindikasikan perilaku manajemen laba yang juga mengukur kualitas akrual. Rendahnya kualitas akrual menunjukkan bahwa auditor tidak mampu dalam membatasi pengaturan akrual diskresioner oleh manajemen, yang menunjukkan kualitas audit yang rendah. Hasil yang diperoleh dari penelitian tersebut mengindikasikan perusahaan yang diaudit oleh KAP yang lebih besar memiliki akrual diskresioner yang lebih kecil. Oleh karena itu, KAP yang lebih besar dianggap kualitas auditnya lebih tinggi.

Dahlan (2009) juga menemukan hubungan negatif antara kualitas audit dengan akrual diskresioner. Artinya, semakin besar kualitas audit akan semakin kecil akrual diskresionernya. Choi et al. (2010) juga menunjukkan akrual diskresioner secara signifikan lebih kecil untuk KAP besar dibanding KAP kecil.

Di lain pihak ada juga penelitian yang menemukan hasil yang berbeda, seperti Fajri (2008) dan Hermawan (2009). Fajri (2008) yang meneliti dengan sampel perusahaan di Indonesia menemukan pengaruh positif antara ukuran KAP dengan akrual diskresioner. Artinya ukuran KAP berpengaruh negatif terhadap kualitas audit. Fajri (2008) menyatakan kemungkinan penyebabnya adalah karena pengawasan pelaksanaan jasa audit oleh regulator kepada KAP Big 4 yang mungkin kurang ketat, yang timbul akibat ketergantungan pasar terhadap KAP Big 4. Ketergantungan ini muncul karena keunggulan KAP Big 4 dibandingkan KAP Non-Big 4 dalam hal kemampuannya memberikan jasa audit yang berkualitas terhadap perusahaan-perusahaan besar. Selain itu faktor rendahnya tingkat kompetisi yang dihadapi KAP Big 4, semakin meningkatkan kekuatan penawaran dari KAP Big 4.

Hermawan (2009) menemukan kualitas audit (yang diukur menggunakan ukuran KAP, yaitu Big 4 dan Non-Big 4) memiliki pengaruh yang negatif dan signifikan dengan ERC, yang artinya informasi laba perusahaan dengan kualitas audit yang tinggi direspon lebih rendah dibanding perusahaan dengan kualitas audit rendah (ukuran KAP berpengaruh negatif dengan kualitas audit). Hermawan (2009) menghubungkan hasil penelitian tersebut dengan Khurana dan Raman (2004) yang menunjukkan bahwa kualitas audit yang lebih tinggi oleh KAP Big 4 hanya terjadi di Amerika Serikat, namun tidak terjadi di negara Australia, Kanada, dan Inggris. Hal tersebut disebabkan oleh faktor risiko litigasi terhadap KAP Big 4 sebagai auditor besar lebih tinggi di Amerika Serikat dibandingkan negara lainnya. Oleh sebab itu, KAP Big 4 lebih memperhatikan kualitas auditnya. Hal ini mengindikasikan KAP Big 4 mungkin tidak akan selalu memberikan kualitas audit yang tinggi karena risiko litigasi yang dihadapi KAP Big 4 di Indonesia relatif kecil. 
Penerbitan laporan auditor memberikan informasi tambahan mengenai kondisi perusahaan bagi para pengguna laporan, seperti investor dan kreditur. Dengan begitu para pengguna laporan dapat menggunakan informasi tersebut sebagai masukan yang sangat berguna dalam pengambilan keputusan. Informasi yang disajikan dalam laporan keuangan hendaknya benar-benar menggambarkan kemampuan perusahaan dalam mempertahankan kelangsungan hidupnya (going concern). Karena eratnya hubungan informasi going concern dengan proses audit, Francis \& Yu (2009) menggunakan penerbitan laporan going concern sebagai proksi dari kualitas audit. Mereka menemukan bahwa ukuran KAP yang besar akan memungkinkan auditornya untuk lebih banyak menerbitkan laporan going concern dan laporan ini lebih akurat dalam memprediksi kebangkrutan di masa depan. Hal ini disebabkan karena KAP yang besar sudah memiliki lebih banyak pengalaman audit sehingga mereka dapat mengidentifikasi masalah going concern secara lebih baik.

Kecenderungan auditor untuk menerbitkan opini going conern juga telah digunakan di penelitian-penelitian sebelumnya untuk pengujian kualitas audit (Reynolds dan Francis 2000; Craswell et al. 2002, DeFond et al. 2002, dalam Francis \& Yu 2009). Auditor yang lebih berkualitas diduga lebih mempunyai keahlian dalam mengidentifikasi kondisi yang menyebabkan perlunya diterbitkan opini going concern (Francis \& Yu 2009). Auditor dapat menjadi ragu-ragu untuk mengeluarkan opini going concern jika manajemen secara implisit maupun eksplisit menyatakan akan memutuskan pengikatan audit jika auditor mengeluarkan opini going concern (Carcello dan Neal 2003). Oleh karena itu, penerbitan opini going concern dapat mencerminkan audit yang berkualitas.

Di sisi lain, penelitian Komalasari (2004) dan Tamba (2009) tidak berhasil membuktikan hal tersebut. Ukuran KAP yang besar tidak membuat KAP tersebut lebih banyak menerbitkan laporan going concern dibandingkan KAP yang lebih kecil. Tamba (2009) menjelaskan kemungkinan hasil tersebut terjadi karena manajer perusahaan yang rasional tidak akan memilih auditor yang berkualitas tinggi dan membayar biaya yang tinggi apabila kondisi perusahaan sedang tidak baik. Hal ini didasari oleh anggapan yang menyebutkan bahwa auditor kualitas yang tinggi yang berada pada KAP besar akan mampu mendeteksi kondisi perusahaan yang tidak baik dan akan menyampaikannya kepada publik. Perusahaan yang menggunakan jasa KAP besar adalah perusahaan yang cenderung memiliki kinerja dan kondisi yang baik, sehingga opini yang diterima kebanyakan adalah opini wajar tanpa pengecualian. Oleh karena itu, perusahaan cenderung tidak memperoleh laporan audit going concern ketika menggunakan jasa KAP yang besar.

Walaupun hasil penelitian yang didapatkan berbeda, namun pada dasarnya penerbitkan laporan audit going concern memang dipengaruhi oleh kemampuan auditor dalam membaca kondisi perusahaan pada saat sekarang maupun untuk masa yang akan datang. Kemampuan auditor tersebut akan terasah mengikuti bertambahnya pengalaman melakukan audit. Hal itulah yang membuat anggapan KAP besar akan lebih banyak menerbitkan laporan audit going concern dibandingkan KAP kecil.

\section{PENGEMBANGAN HIPOTESIS}

Proses audit yang berkualitas sangatlah penting untuk menghasilkan informasi akuntansi yang berkualitas yang sangat relevan bagi para pengguna laporan keuangan. Namun proses audit yang berkualitas hanya dapat dihasilkan apabila proses audit dilakukan oleh auditor yang benarbenar kompeten dan independen. Alim et al. (2007), dalam Christiawan (2002), mengatakan kualitas audit ditentukan oleh dua hal yaitu, kompetensi dan independensi. Selanjutnya DeAngelo (1981) menggunakan ukuran auditor sebagai proksi dari kualitas audit.

DeAngelo (1981) menunjukkan KAP besar (big 4 accounting firms) akan melakukan audit dengan lebih berkualitas dibandingkan dengan KAP kecil (non big 4 accounting firms). Francis \& $\mathrm{Yu}$ (2009) memberikan bukti empiris yang mendukung hubungan positif antara ukuran KAP dan kualitas audit. Francis \& Yu (2009) meneliti apakah ukuran KAP khususnya KAP Big 4, yang diproksikan dengan pendapatan audit dan jumlah klien, akan mempengaruhi kualitas audit. Kualitas audit dilihat dari kualitas akrual klien yang disajikan dalam laporan keuangan dan laporan audit going concern yang diterbitkan oleh KAP. Francis \& Yu (2009) berargumen bahwa hanya KAP Big 4 yang berukuran besar yang akan menghasilkan kualitas audit yang tinggi dengan menunjukkan kemampuannya dalam membatasi perilaku manajemen laba dan menerbitkan laporan audit going concern. Francis \& Yu (2009) membuktikan bahwa KAP Big 4 dengan ukuran besar mampu menghasilkan kualitas audit yang lebih baik dibandingkan KAP Big 4 yang berukuran kecil. Sejalan dengan Francis \& Yu (2009), penelitian Choi et al. (2010) juga membuktikan bahwa ukuran auditor merupakan faktor yang mempengaruhi kualitas audit. 
Berdasarkan penjelasan tersebut, penelitian ini akan menguji hipotesis pertama mengenai pengaruh ukuran KAP terhadap kualitas audit (yang diukur menggunakan manajemen laba). Penelitian ini akan menguji keseragaman kualitas audit KAP baik KAP Big 4 maupun KAP Non-Big 4 yang mengaudit perusahaan manufaktur yang terdaftar di Bursa Efek Indonesia. Selain menguji kualitas audit pada seluruh KAP, penelitian ini juga menguji secara terpisah terhadap kelompok sampel yang merupakan klien KAP Big 4 dan kelompok sampel yang merupakan klien KAP Non-Big 4.

H1: Ukuran kantor akuntan publik yang besar memiliki kemampuan mendeteksi manajemen laba yang lebih baik daripada ukuran kantor akuntan publik yang kecil

Selain menguji pengaruh ukuran KAP terhadap manajemen laba (kualitas akrual) yang disajikan oleh klien, penelitian ini juga menguji pengaruh ukuran KAP terhadap laporan audit going concern yang diterbitkan oleh KAP. Penerbitan laporan audit going concern dianggap oleh Francis \& Yu (2009) juga merupakan salah satu proksi kualitas audit sehingga diekspektasikan akan dipengaruhi oleh ukuran KAP.

Laporan audit going concern memberikan informasi mengenai keadaan keuangan perusahaan di masa yang akan datang, akan terus berlanjut atau terdeteksi akan mengalami kebangkrutan. Penerbitan laporan audit going concern sangat tidak diharapkan oleh manajemen, karena dapat menyebabkan ketidakpercayaan para pengguna laporan terhadap manajemen perusahaan yang pada akhirnya mengantarkan perusahaan ke gerbang kebangkrutan yang sesungguhnya.

Kemampuan auditor dalam mendeteksi kebangkrutan kliennya sangatlah penting agar dapat membantu para pengguna laporan dalam mengambil keputusan dan juga menjaga reputasi auditor. Keberhasilan auditor dalam menilai keadaan perusahaan klien dan menuangkannya ke dalam sebuah laporan audit dianggap sebagai kualitas audit. Francis \& Yu (2009) menemukan pengaruh positif ukuran KAP Big 4 dalam penerbitan laporan audit going concern untuk perusahaan di Amerika. Artinya ukuran KAP Big 4 yang besar akan lebih tinggi kecenderungannya mengeluarkan laporan audit going concern (kualitas audit yang tinggi). Hipotesis kedua dirumuskan untuk menguji pengaruh ukuran KAP terhadap kemungkinan dikeluarkannya laporan audit going concern:

H2: Ukuran kantor akuntan publik yang besar lebih besar kemungkinannya menerbitkan laporan audit going concern daripada ukuran kantor akuntan publik yang kecil.
Ukuran KAP yang digunakan sebagai variabel bebas digambarkan dengan jumlah rekan, jumlah auditor, jumlah klien, dan jumlah pendapatan audit. Sedangkan untuk mengukur kualitas audit digunakan 2 variabel yaitu akrual diskresioner (manajemen laba) dan laporan audit going concern. Berdasarkan studi empiris sebelumnya, akrual diskresioner dipengaruhi oleh sejumlah variabel, yang dimasukkan menjadi variabel kontrol, yaitu arus kas operasi (CFO), CFO Volatility, kas dan setara kas, pertumbuhan penjualan (Sales Growth), kerugian operasi (Loss), Lag Loss, Tenure AP, Tenure KAP, ukuran perusahaan (Size), utang (Debt) dan Market to Book Value $(M B)$. Sedangkan variabel laporan audit going concern dipengaruhi oleh kas dan setara kas (Cash), utang (Debt), Sales Volatility, kerugian operasi (Loss), Lag Loss, Tenure AP, Tenure KAP, ukuran perusahaan (Size), dan Market-to-Book Value $(M B)$.

\section{METODE PENELITIAN}

Untuk mengetahui pengaruh ukuran KAP dengan kualitas audit yang dihasilkan, penelitian ini menggunakan dua model penelitian. Dengan mengadaptasi penelitian Francis \& Yu (2009), untuk menguji hipotesis pertama (H1) dengan tujuan melihat pengaruh ukuran KAP terhadap kualitas akrual akan dilakukan analisis regresi berganda dengan model seperti berikut:

$A C C R U A L S_{i t}=\lambda_{0}+\lambda_{1} L N \_J R_{i t}+\lambda_{2} L N \_J A_{i t}+\lambda_{3} L N \_J K_{i t}$ $+\lambda_{4} L N_{\_} J P_{i t}+\lambda_{5} C F O_{i t}+\lambda_{6} C F O \_V O L_{i t}+\lambda_{7} D E B T_{i t}+$ $\lambda_{8} S A L E S S_{-} V O L_{i t}+\lambda_{9} S A L E S \_G R_{i t}+\lambda_{10} L O S S_{i t}+$ $\lambda_{11} L A G_{-} L O S S_{i t}+\lambda_{12}$ TENURE_AP ${ }_{i t}+\lambda_{13}$ TENURE $\_K A P_{i t}+\lambda_{14} S I Z E_{i t}+\lambda_{15} M B_{i t}+\varepsilon_{i t}$

Variabel kontrol CFO dimasukkan ke dalam model karena CFO dianggap berpengaruh negatif terhadap akrual diskresioner. Dechow et al. (1995) menunjukkan bahwa arus kas operasi mempengaruhi nilai dari akrual diskresioner dan diekspektasikan CFO yang semakin besar akan menghasilkan akrual diskresioner yang semakin kecil. Hal ini kemungkinan disebabkan karena ketika perusahaan memiliki arus kas operasi yang kecil, dimana mengindikasikan keuangan perusahaan sedang tidak baik, perusahaan cenderung menggunakan akrual diskresioner untuk menutupi kelemahan tersebut. Selain itu, terdapat beberapa penelitian yaitu Doyle et al. (2007) dan Hribar dan Nichols (2007) yang menunjukkan adanya hubungan yang positif antara volatilitas arus kas dengan nilai akrual, sehingga variabel CFO_VOLATILITY dimasukkan ke dalam model penelitian ini.

Variabel yang menggambarkan penurunan kondisi keuangan yang juga digunakan sebagai variabel kontrol adalah DEBT, LOSS dan LAG_ 
LOSS. Francis \& Yu (2009) menyatakan bahwa perusahaan yang memiliki lebih banyak utang akan lebih sering menggunakan akrual dalam meningkatkan laba, sehingga diprediksi tingkat utang akan memiliki korelasi yang positif dengan akrual diskresioner. Perusahaan dengan laba yang negatif diekspektasikan juga akan memiliki hubungan yang negatif dengan kualitas akrual, artinya perusahaan yang melaporkan kerugian tidak memiliki lebih banyak insentif untuk memainkan labanya dibandingkan perusahaan yang melaporkan laba positif.

Becker et al. (1998) menyebutkan perusahaan yang lebih besar cenderung memiliki kualitas laba yang lebih besar, sehingga diekspektasikan ukuran perusahaan (SIZE) yang diukur dengan natural logaritma dari total asset klien akan berkorelasi negatif dengan akrual. Hal ini dikarenakan perusahaan besar memiliki sumber daya, baik manusia dan modal, yang lebih baik dibandingkan perusahaan kecil. Dengan sumber daya yang lebih baik, perusahaan dapat mengembangkan dan menciptakan sistem pengendalian internal yang lebih baik di dalam kegiatan operasinya, sehingga praktek manajemen laba dapat dikendalikan. Sedangkan SALES_GR ditemukan memiliki korelasi yang positif dengan akrual abnormal oleh Mcnon dan Williams (2004), karena perusahaan yang sedang berkembang, akan memiliki risiko lebih besar untuk gagal sehingga akan cenderung melakukan manajemen laba. Dan sama seperti CFO_VOLATILITY, SALES_VOLATILITY juga didasarkan pada penelitian Hibrar dan Nichols (2007), diduga berpengaruh positif terhadap akrual.

TENURE_AP dan TENURE_KAP merupakan variabel kontrol yang berkaitan dengan auditor. Variabel ini dimasukkan ke dalam model dengan didasarkan oleh penelitian Johnson et al. (2002) dan Pratiwi (2010) yang menemukan bahwa periode pemberian jasa audit oleh AP yang singkat akan meningkatkan jumlah akrual diskresioner. Rendahnya kualitas audit ini kemungkinan disebabkan karena belum terciptanya kurva pembelajaran sehingga auditor belum dapat membaca kondisi perusahaan yang sebenarnya. Hal ini berlaku juga untuk TENURE_KAP. Sedangkan variabel yang berdasarkan pasar, yaitu market to book value ratio (MB) dimasukkan karena tekanan pasar modal dapat mempengaruhi perilaku manajemen laba perusahaan. Perusahaan yang memiliki risiko pertumbuhan lebih besar lebih cenderung melakukan manajemen laba untuk mencapai ekspektasi pasar. Oleh karena itu variabel ini diekspektasikan memiliki koefisien yang positif dengan akrual.

Berbeda dengan H1, untuk hipotesis kedua (H2), analisis regresi yang akan digunakan adalah analisis regresi logistik:

\section{$G C \_O P I N_{i t}=\beta_{0}+\beta_{1} L N_{\_} J R_{i t}+\beta_{2} L N_{\_} J A_{i t}+\beta_{3} L N_{-}$ $J K_{i t}+\beta_{4} L N_{\_} J P_{i t}+\beta_{5} C A S H_{i t}+\beta_{6} D E B T_{i t}+$ $\beta_{7} S A L E S \_V O L i t+\beta_{8} L O S S_{i t}+\beta_{9} L A G_{-} L O S S_{i t}$ $+\beta_{10}$ TENURE_AP $i t+\beta_{11}$ TENURE_KAP ${ }_{i t}+$ $\beta_{12} S I Z E_{i t}+\beta_{13} M B_{i t}+\varepsilon_{i t}$}

Variabel kas dan setara kas (CASH) merupakan variabel pengendali terkait ukuran likuiditas. Perusahaan dengan lebih banyak aset yang likuid diduga akan memiliki kemampuan yang lebih baik dalam menghadapi masalah keuangan. Oleh karena itu, variabel ini diekspektasikan berpengaruh negatif terhadap opini audit going concern. Begitu juga dengan SIZE yang menggambarkan total aset klien, diekspektasikan berkorelasi negatif dengan opini audit going concern karena klien yang lebih besar akan memiliki lebih banyak sumber daya untuk mencegah terjadinya kebangkrutan. TENURE_AP dan TENURE_KAP diprediksi bernilai positif terhadap audit going concern.

Perusahaan dengan utang yang banyak (DEBT) dan perusahaan yang melaporkan kerugian (LOSS) lebih cenderung akan gagal atau memiliki kesangsian dalam kelangsungan perusahaannya, sehingga akan lebih cenderung menerima laporan audit going concern. Sedangkan variabel SALES_VOLATILITY dan MB diekspektasikan berhubungan positif dengan laporan audit going concern karena perusahaan yang sedang berkembang memiliki risiko yang lebih besar sehingga lebih berisiko mengalami kegagalan.

\section{Operasionalisasi Variabel}

Variabel kualitas audit yang pertama adalah akrual diskresioner (ACCRUALS), menggunakan model Kasznik (1999):

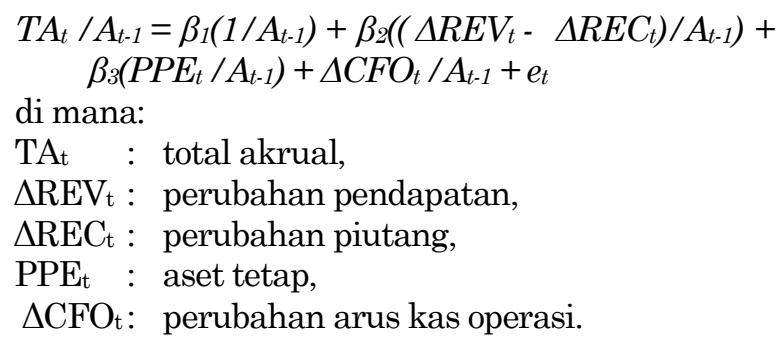

Total akrual diperoleh dari selisih laba bersih dan arus kas operasi. Nilai akrual diskresioner adalah nilai residual $\left(\mathrm{e}_{\mathrm{t}}\right.$ ) model Kasznik di atas.

Ukuran kualitas audit yang kedua adalah opini audit going concern (GC_OPIN). Nilai 1 diberikan apabila perusahaan yang diaudit oleh KAP menerima laporan audit going concern dan 0 apabila sebaliknya.

KAP Big 4 adalah KAP Haryanto Sahari yang berafiliasi dengan PricewaterhouseCoopers, KAP Osman Bing Satrio yang berafiliasi dengan 
Deloitte Touche Tohmatsu, KAP Purwantono, Sarwoko, Sandjaja yang berafiliasi dengan Ernst \& Young dan KAP Siddharta, Siddharta, Widjaja yang berafiliasi dengan KPMG, dan KAP lainnya adalah KAP Non-Big 4. Penelitian ini mengukur ukuran KAP dengan beberapa macam ukuran, yaitu jumlah rekan (LN_JR), jumlah auditor (LN_JA), jumlah klien (LN_JK) dan jumlah pendapatan yang dimiliki oleh KAP (LN_JP). Semua ukuran ditransformasikan menggunakan logaritma natural.

Beberapa variabel kontrol yang digunakan adalah Cash flow from operation (CFO), yang diukur dari arus kas operasi dibagi dengan total aset tahun sebelumnya; CFO volatility (CFO_VOL) yang merupakan standar deviasi dari CFO selama tiga tahun; Kas dan setara kas (CASH) merupakan jumlah kas dan setara kas dibagi dengan total aset, pertumbuhan penjualan (SALES_GR) adalah tingkat pertumbuhan dari penjualan, Sales Volatility (SALES_VOL) merupakan standar deviasi dari penjualan selama tiga tahun, Loss (LOSS) merupakan variabel dummy, yaitu 1 apabila laba operasi setelah penyusutan adalah negatif dan 0 apabila yang lainnya, Lag loss (LAG_LOSS) juga merupakan variabel dummy, yaitu 1 apabila laba operasi setelah penyusutan tahun sebelumnya adalah negatif dan 0 apabila yang lainnya, Tenure (TENURE_AP dan TENURE_KAP) menunjukkan lamanya periode audit baik untuk akuntan publik (TENURE_AP) maupun kantor akuntan publik (TENURE_KAP), ukuran perusahaan (SIZE) diukur dengan natural logaritma dari aset klien, utang (DEBT) adalah rasio jumlah kewajiban klien dibagi jumlah aset, Market to Book Value (MB) merupakan natural log dari rasio market value of equity to its book value of equity yang dimiliki oleh klien.

Penelitian dilakukan dengan menggunakan populasi yang mencakup seluruh kantor akuntan publik baik KAP Big 4 maupun Non-Big 4. Untuk KAP Big 4 yang digunakan adalah KAP yang berafiliasi dengan Deloitte, Ernst \& Young, KPMG dan Pricewaterhouse Cooper yang ada di Indonesia dan sisanya dianggap sebagai KAP Non-Big 4. Sedangkan untuk sampel perusahaan digunakan perusahaan manufaktur yang terdaftar di Bursa Efek Indonesia selama periode 2006-2008. Alasan penggunaan sampel hanya pada satu industri yaitu manufaktur adalah untuk memperoleh homogenitas dalam sampel karena setiap industri memiliki karakteristik masing-masing yang berbeda satu sama lainnya. Selain itu, pemilihan perusahaan manufaktur sebagai sampel penelitian juga disebabkan karena persentase perusahaan manufaktur yang terdaftar di Bursa Efek Indonesia lebih banyak dari jumlah perusahaan pada kelompok industri lainnya.
Berikut adalah kriteria pemilihan sampel: 1) Perusahaan manufaktur yang terdaftar pada Bursa Efek Indonesia selama tahun 2006-2008, 2) Perusahaan manufaktur yang mempunyai laporan keuangan lengkap selama 3 tahun (tahun 2006 sampai 2008), 3) Memiliki tanggal tutup buku 31 Desember.

\section{ANALISIS DAN PEMBAHASAN}

Tabel 1 menggambarkan proses pemilihan sampel. Berdasarkan kriteria pemilihan sampel diperoleh jumlah sampel sebanyak 348 tahunperusahaan.

\section{Tabel 1. Pemilihan Sampel}

\begin{tabular}{lc}
\hline \multicolumn{1}{c}{ Kriteria } & Jumlah \\
\hline $\begin{array}{l}\text { Perusahaan manufaktur yang terdaftar } \\
\text { pada Bursa Efek Indonesia 2006, 2007, dan }\end{array}$ & \\
2008. & 435 \\
$\begin{array}{l}\text { Perusahaan manufaktur yang datanya } \\
\text { tidak lengkap. }\end{array}$ & $(87)$ \\
$\begin{array}{l}\text { Jumlah sampel keseluruhan (Perusahaan } \\
\text { manufaktur yang diaudit oleh KAP Non-Big }\end{array}$ & \\
$\begin{array}{l}\text { 4 dan KAP Big 4) } \\
\text { Perusahaan manufaktur yang diaudit oleh }\end{array}$ & 348 \\
$\begin{array}{l}\text { KAP Non-Big 4 } \\
\text { Perusahaan manufaktur yang diaudit oleh }\end{array}$ & 182 \\
KAP Big 4 & 166 \\
\hline
\end{tabular}

Tabel 2 dan 3 menyajikan hasil dari statistik deskriptif untuk seluruh sampel dan juga untuk sub sampel perusahaan manufaktur yang merupakan klien KAP Big 4 dan yang merupakan klien KAP Non-Big 4. Nilai rata-rata dari akrual diskresioner (ACCRUALS) adalah 0,109 dengan standar deviasi 0,105. Hal tersebut menandakan bahwa perusahaan sampel mempunyai variasi yang cukup tinggi dalam melakukan manajemen laba. Namun, apabila dilihat dari statistik deskriptif antara kelompok klien Big 4 dan Non-Big 4, nilai rata-rata untuk klien KAP Non-Big 4 lebih kecil bila dibandingkan yang terjadi pada klien KAP Big 4. Hal tersebut mengindikasikan bahwa perusahaan yang merupakan klien KAP Big 4 melakukan manajemen laba yang lebih besar dibanding perusahaan yang merupakan klien KAP Non-Big 4.

Variabel GC_OPIN menunjukkan hanya 25\% dari seluruh perusahaan manufaktur yang menerima laporan audit going concern. Untuk kelompok perusahaan manufaktur yang merupakan klien KAP Big 4, hanya sebesar 15\% yang menerima laporan audit going concern, sedangkan klien KAP Non-Big 4 ada sekitar $35 \%$. Hal tersebut menunjukkan KAP Non-Big 4 lebih banyak menerbitkan laporan audit going concern, yang dapat menjadi indikasi kualitas audit yang lebih berkualitas. 
Tabel 2. Statistik Deskriptif Model 1

\begin{tabular}{|c|c|c|c|c|c|c|c|c|c|c|c|c|}
\hline \multirow{2}{*}{ Variabel } & \multicolumn{4}{|c|}{ Big 4 dan Non-Big $4(n=348)$} & \multicolumn{4}{|c|}{ Big $4(n=166)$} & \multicolumn{4}{|c|}{ Non-Big $4(n=182)$} \\
\hline & Min & $\operatorname{Max}$ & Mean & Std Dev & Min & $\operatorname{Max}$ & Mean & $t d D e v$ & Min & $\operatorname{Max}$ & Mean & Std Dev \\
\hline $\mathrm{CC}$ & 0,0006 & 0,902 & 0,109 & 0,105 & 0,002 & 0,902 & 0,136 & 0,121 & 0,0006 & 0,547 & 0,084 & 0,082 \\
\hline $\mathrm{D}$ & 1,00 & 4,00 & & & 8,00 & 24,00 & 14,699 & 728 & 1,00 & 12,00 & & \\
\hline A & 3,00 & 0 & 0 & & 0 & 98 & & & 00 & 00 & & \\
\hline$z$ & 0 & 0 & 3 & & 290 , & 73 & 2 & & 00 & & & \\
\hline 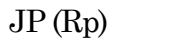 & 0,00 & 45 & & & & 45 & 30 & & 0,00 & M & M & \\
\hline FO & $-0,719$ & 86 & 0 & & $-0,524$ & 0,3 & & & $-0,719$ & 0,361 & 04 & 33 \\
\hline $\mathrm{FO}_{-}$ & 0,007 & 0,396 & 0 & & 0,007 & 0,3 & 5 & & 0,011 & 0,396 & 26 &, 087 \\
\hline EBT & 0,071 & 2,995 & 0,623 & & 0,071 & $1, \frac{5}{2}$ & 0,546 & & 0,090 & 2,995 & 93 & 0,555 \\
\hline AI & $-1,00$ & 53,395 & 0,408 & 2,980 & $-0,352$ & 53,395 & 0,599 & 4,250 & $-1,00$ & 5,123 & 0,233 & 0,675 \\
\hline$\Delta \mathrm{I}$ & 2 Juta & $21 \mathrm{M}$ & 44 Juta & ta & 9 Juta & 21 & & $3,2 \mathrm{M}$ & Juta & $0,4 \mathrm{M}$ & 2 Juta & $4 \mathrm{M}$ \\
\hline OS & 0,00 & 1,00 & 0,147 & 4 & 0,00 & 0 & & 2 & 0,00 & 1,00 & 0,181 &, 386 \\
\hline $\mathrm{AAC}$ & 0,00 & 1,00 & 0,1 & & 0,00 & 1,00 & 0,108 & & 0,00 & 1,00 & 0,187 & ),391 \\
\hline $\mathrm{EN}$ & 1,00 & 5,00 & 1,796 & & 1,00 & 4,00 & 1,790 & 0,824 & 1,00 & 5,00 & 1,801 & 0,876 \\
\hline EN & 1,00 & 7,00 & 2 & & 1,00 & 7,00 & 2,406 & 1,463 & 1,00 & 6,00 & 2,494 & 1,448 \\
\hline$[\mathrm{ZE}$ & Juta &, $7 \mathrm{M}$ & $\Lambda$ & & Juta & $0,7 \mathrm{M}$ & $4,99 \mathrm{M}$ & $10,4 \mathrm{M}$ & Jut: & $76,4 \mathrm{M}$ & $2,18 \mathrm{M}$ & $8,15 \mathrm{M}$ \\
\hline IB & 135 & ,762 & 0,006 & 1,050 & $-2,256$ & 3,762 & 0,296 & 1,029 & $-3,135$ & 2,454 & $-0,258$ & 1,001 \\
\hline
\end{tabular}

Tabel 3. Statistik Deskriptif Model 2

\begin{tabular}{|c|c|c|c|c|c|c|c|c|c|c|c|c|}
\hline \multirow{2}{*}{ Variabel } & \multicolumn{4}{|c|}{ Big 4 dan Non-Big $4(n=348)$} & \multicolumn{4}{|c|}{ Big $4(n=166)$} & \multicolumn{4}{|c|}{ Non-Big $4(n=182)$} \\
\hline & Min & $\operatorname{Max}$ & Mean & Std Dev & Min & $\operatorname{Max}$ & Mean & Std Dev & Min & $\operatorname{Max}$ & Mean & Std Dev \\
\hline$\overline{\text { GC_OPIN }}$ & 0,00 & 10,00 & 0,251 & 0,434 & 0,00 & 1,00 & 0,151 & 0,359 & 0,00 & 1,00 & 0,347 & $\overline{0,477}$ \\
\hline JR & 1,00 & 24,00 & 9,856 & 5,809 & 8,00 & 24,00 & 14,699 & 3,728 & 1,00 & 12,00 & 5,208 & 2,936 \\
\hline JA & 3,00 & 981,00 & 299,70 & 288,76 & 88,00 & 981,00 & 527,47 & 286,26 & 3,00 & 337,00 & 118,02 & 100,94 \\
\hline JK & 3,00 & 739,00 & 336,93 & 219,87 & 290,00 & 739,00 & 505,22 & 161,74 & 3,00 & 658,00 & 229,91 & 181,78 \\
\hline $\mathrm{JP}(\mathrm{Rp})$ & 0,00 & $453 \mathrm{M}$ & $158 \mathrm{M}$ & $1,71 \mathrm{M}$ & $18 \mathrm{M}$ & $453 \mathrm{M}$ & $305 \mathrm{M}$ & $126 \mathrm{M}$ & 0,00 & $43,9 \mathrm{M}$ & $13,9 \mathrm{M}$ & $13,2 \mathrm{M}$ \\
\hline DEBT & 0,071 & 2,995 & 0,623 & 0,441 & 0,071 & 1,587 & 0,546 & 0,244 & 0,090 & 2,995 & 0,693 & 0,555 \\
\hline CASH & 0,0002 & 0,480 & 0,081 & 0,092 & 0,003 & 0,480 & 0,103 & 0,095 & 0,0002 & 0,462 & 0,0613 & 0,085 \\
\hline SALES_VOL & 1,2 Juta & $21 \mathrm{M}$ & 944 Juta & 250 Juta 3 & 3,9 Juta & $21 \mathrm{M}$ & $1,4 \mathrm{M}$ & $3,2 \mathrm{M}$ & 1,2 Juta & $10,4 \mathrm{M}$ & 492 Juta & $1,4 \mathrm{M}$ \\
\hline LOSS & 0,00 & 1,00 & 0,147 & 0,354 & 0,00 & 1,00 & 0,108 & 0,312 & 0,00 & 1,00 & 0,181 & 0,386 \\
\hline LAG_LOSS & 0,00 & 1,00 & 0,149 & 0,357 & 0,00 & 1,00 & 0,108 & 0,312 & 0,00 & 1,00 & 0,187 & 0,391 \\
\hline TEN_AP & 1,00 & 5,00 & 1,796 & 0,850 & 1,00 & 4,00 & 1,790 & 0,824 & 1,00 & 5,00 & 1,801 & 0,876 \\
\hline TEN_KAP & 1,00 & 7,00 & 2,452 & 1,453 & 1,00 & 7,00 & 2,406 & 1,463 & 1,00 & 6,00 & 2,494 & 1,448 \\
\hline SIZE (Rp) & 24 Juta & $80,7 \mathrm{M}$ & $3,52 \mathrm{M}$ & $9,39 \mathrm{M}$ & 34 Juta & $80,7 \mathrm{M}$ & $4,99 \mathrm{M}$ & $10,4 \mathrm{M}$ & 24 Juta & $76,4 \mathrm{M}$ & $2,18 \mathrm{M}$ & $8,15 \mathrm{M}$ \\
\hline MB & $-3,135$ & 3,762 & 0,006 & 1,050 & $-2,256$ & 3,762 & 0,296 & 1,029 & $-3,135$ & 2,454 & $-0,258$ & 1,001 \\
\hline
\end{tabular}

Untuk variabel JR, JA, JK dan JP yang menggambarkan ukuran KAP, hasil dari nilai terendah keempat variabel terdapat pada kelompok klien KAP Non-Big4 dan untuk nilai tertingginya terdapat pada kelompok klien KAP Big 4. Hasil tersebut berlaku untuk ukuran KAP yang didasarkan pada jumlah rekan, jumlah auditor, jumlah klien maupun berdasarkan jumlah pendapatan KAP per tahunnya. Hal tersebut wajar karena KAP Big 4 memiliki ukuran yang lebih besar dibanding KAP Non-Big 4.

Hasil dari korelasi Pearson dapat dilihat pada tabel 4, 5, dan 6. Korelasi antara LN_JA, LN_JR, LN_JK, LN_JP dengan ACCRUALS adalah positif dan signifikan. Hal ini tidak sesuai dengan penelitian terdahulu dan juga ekspektasi koefisien, yaitu negatif (perusahaan manufaktur yang diaudit oleh KAP yang berukuran lebih besar akan menghasilkan akrual diskresioner yang kecil).
ACCRUALS memiliki korelasi yang tidak signifikan dengan CFO (berbeda dengan ekspektasi, yaitu semakin tinggi arus kas operasi akan semakin kecil akrual diskresionernya). Selain itu, variabel ACCRUALS juga memiliki korelasi yang positif signifikan dengan variabel LOSS dan LAG_LOSS. Hal ini berarti ketika kerugian terjadi pada suatu perusahaan, perusahaan tersebut berusaha mempercantik keadaan perusahaan dengan melakukan manajemen laba (dengan meningkatkan akrual diskresioner).

Terdapat korelasi yang positif antara ACCRUALS dengan TENURE_AP maupun TENURE_KAP, menandakan bahwa semakin lama hubungan suatu KAP Big 4 dengan klien, maka akrual diskresioner klien tersebut akan semakin besar. Hal tersebut menyiratkan kualitas audit KAP akan terpengaruh dengan panjangnya jangka waktu audit. 
Dari pengujian multikolinearitas diketahui adanya multikolinearitas yang tinggi, sehingga diputuskan mengeluarkan dua variabel LN_JK dan LN_JP, sehingga model baru yang dijadikan model utama dalam penelitian ini, yaitu:

\section{$A C C R U A L S_{i t}=\lambda_{0}+\lambda_{1} L N \_J R_{i t}+\lambda_{2} L N \_J A_{i t}+$ $\lambda_{3} \mathrm{CFO}_{i t}+\lambda_{4} \mathrm{CFO} \mathrm{VOL}_{i t}+\lambda_{5} \mathrm{DEBT} \mathrm{T}_{i t}+$ $\lambda_{6} S A L E S \_V O L i t+\lambda_{7} S A L E S \_G R_{i t}+\lambda_{8} L O S S_{i t}$ $+\lambda_{9} L A G \_L O S S_{i t}+\lambda_{10}$ TENURE_AP $P_{i t}+\lambda_{11}$ $T E N U R E \_K A P_{i t}+\lambda_{12} S I Z E_{i t}+\lambda_{13} M B_{i t}+\varepsilon_{i t}$}

Tabel 7 menunjukkan hasil regresi dari model di atas. Adjusted $\mathrm{R}^{2}$ adalah 0,245 untuk keseluruhan sampel, sedangkan ketika sampel dibagi menjadi 2 kelompok, nilai adjusted $\mathrm{R}^{2}$ untuk kelompok klien Big 4 adalah 0,310 dan untuk kelompok klien Non-Big 4 adalah 0,064. Ketika sampel dibagi menjadi kelompok klien KAP Big 4 dan Non-Big 4, nilai adjusted $\mathrm{R}^{2}$ untuk sampel klien KAP Big 4 meningkat menjadi 31\%, artinya semakin banyak variasi ACCRUALS yang dapat dijelaskan oleh variabel-variabel bebas. Sebalik- nya, ketika sampel dikelompokkan ke dalam kelompok klien KAP Non-Big 4, nilai adjusted $\mathrm{R}^{2}$ cenderung menurun cukup jauh menjadi hanya 6\%. Dari uji F tersebut, didapat F hitung adalah 6,119 dengan tingkat signifikansi 0,0000. Model H1 ini dapat digunakan untuk memprediksi ACCRUALS. Hal serupa juga terjadi ketika sampel dikelompokkan menjadi klien KAP Big 4. Namun pada saat dikelompokkan ke dalam klien KAP Non-Big 4, F hitung menjadi sangat kecil yaitu 1,531 dengan F statistik sebesar 0,122. Hal ini menandakan model dengan pengelompokkan klien KAP Non-Big 4 tidak dapat menjelaskan variasi dari variabel dependen, sehingga tidak bisa dianalisis lebih lanjut.

Dari Tabel 7 dapat dilihat bahwa LN_JR sebagai salah satu ukuran KAP tidak berpengaruh signifikan terhadap ACCRUALS. Hasil ini tidak konsisten dengan ekspektasi maupun penelitian Francis \& Yu (2009) dan Choi et al. (2010), namun konsisten dengan Pratiwi (2010) dan Pardede (2010).

Tabel 4. Korelasi Pearson (Klien Big 4 dan Non Big 4)

\begin{tabular}{|c|c|c|c|c|c|c|c|c|c|c|c|c|c|c|c|c|}
\hline & ACC & $\overline{\text { LN_JR }}$ & LN_JA & LN_JK & LN_JP & CFO & CFO_V & DEBT & S_GR & S_VOL & LOSS & LAG_L & T_AP & T_KAP & SIZE & MB \\
\hline ACC & 1 & $0,177^{\text {** }}$ & $0,135^{*}$ & 0,091 & $0,141^{* *}$ & 0,103 & 0,092 & $-0,008$ & 0,099 & 0,049 & $0,131^{*}$ & $0,133^{*}$ & 0,012 & 0,065 & 0,029 & $0,264^{* *}$ \\
\hline LN_JR & $0,177^{\text {** }}$ & 1 & $0,773^{* *}$ & $0,733^{* *}$ & $0,709^{* *}$ & 0,089 & $-0,032$ & $-0,18^{* *}$ & 0,062 & 0,090 & $-0,018$ & $-0,069$ & $-0,038$ & $-0,131^{*}$ & $0,255^{* *}$ & $0,134^{*}$ \\
\hline LN_JA & $0,135^{*}$ & $0,773^{* *}$ & 1 & $0,931^{* *}$ & $0,777^{\text {** }}$ & $0,113^{*}$ & $-0,090$ & $-0,22^{* *}$ & 0,055 & $0,177^{* *}$ & $-0,22^{* *}$ & $-0,188^{* *}$ & 0,088 & $0,181^{* *}$ & $0,366^{* *}$ & 0,089 \\
\hline LN_JK & 0,091 & $0,733^{* *}$ & $0,931^{* *}$ & 1 & $0,783^{* *}$ & $0,108^{*}$ & $-0,094$ & $-0,22^{* *}$ & 0,039 & $0,126^{*}$ & $-0,24^{\text {** }}$ & $-0,187^{\text {*** }}$ & 0,050 & $0,120^{*}$ & $0,310^{* *}$ & 0,040 \\
\hline LN_JP & $0,141^{* *}$ & $0,709^{* * *}$ & $0,777^{* *}$ & $0,783^{* *}$ & 1 & 0,095 & $-0,098$ & $-0,19^{* *}$ & 0,036 & $0,175^{* *}$ & $-0,14^{* *}$ & $-0,228^{* *}$ & 0,049 & 0,110 & $0,377^{* *}$ & 0,074 \\
\hline CFO & 0,103 & 0,089 & $0,113^{*}$ & $0,108^{*}$ & 0,095 & 1 & $-0,101$ & $-0,006$ & 0,018 & 0,078 & $-0,004$ & 0,052 & $-0,027$ & $-0,047$ & 0,059 & 0,039 \\
\hline CFO_VOL & 0,092 & $-0,032$ & $-0,090$ & $-0,094$ & $-0,098$ & $-0,10$ & 1 & $0,122^{*}$ & $-0,006$ & $-0,15^{* *}$ & 0,036 & 0,027 & 0,069 & 0,003 & $-0,28^{* *}$ & 0,032 \\
\hline DEBT & $-0,008$ & $-0,182^{* *}$ & $-0,22^{* *}$ & $-0,22^{* *}$ & $-0,19^{* *}$ & $-0,006$ & $0,122^{*}$ & 1 & 0,009 & $-0,030$ & $0,310^{* *}$ & $0,308^{* *}$ & $-0,009$ & $-0,126^{*}$ & $-0,049$ & 0,050 \\
\hline S_GR & 0,099 & 0,062 & 0,055 & 0,039 & 0,036 & 0,018 & $-0,006$ & 0,009 & 1 & $0,199^{* *}$ & $0,121^{*}$ & 0,008 & 0,002 & $-0,020$ & $0,113^{*}$ & $-0,043$ \\
\hline S_VOL & 0,049 & 0,090 & $0,177^{* *}$ & $0,126^{*}$ & $0,175^{* *}$ & 0,078 & $-0,15^{* *}$ & $-0,030$ & $0,199^{* *}$ & 1 & $-0,039$ & $-0,074$ & $-0,027$ & $0,153^{* *}$ & $0,591^{* *}$ & 0,016 \\
\hline LOSS & $0,131^{*}$ & $-0,018$ & $-0,22^{* *}$ & $-0,24^{* *}$ & $-0,14^{* *}$ & $-0,004$ & 0,036 & $0,310^{* *}$ & $0,121^{*}$ & $-0,039$ & 1 & $0,578^{* *}$ & 0,011 & $-0,15^{\text {** }}$ & $-0,126^{*}$ & $-0,120$ \\
\hline L_LOSS & $0,133^{*}$ & $-0,069$ & $-0,19^{* *}$ & $-0,19^{* *}$ & $-0,23^{* *}$ & 0,052 & 0,027 & $0,308^{* *}$ & 0,008 & $-0,074$ & $0,578^{* *}$ & 1 & $-0,040$ & $-0,108$ & $-0,16^{* *}$ & $-0,022$ \\
\hline T_AP & 0,012 & $-0,038$ & 0,088 & 0,050 & 0,049 & $-0,027$ & 0,069 & $-0,009$ & 0,002 & $-0,027$ & 0,011 & $-0,040$ & 1 & $0,406^{\text {** }}$ & $-0,058$ & 0,072 \\
\hline T_KAP & 0,065 & $-0,131^{*}$ & $0,181^{* *}$ & $0,120^{*}$ & 0,110 & $-0,047$ & 0,003 & $-0,126^{*}$ & $-0,020$ & $0,153^{* *}$ & $-0,15^{* *}$ & $-0,108$ & $0,406^{\text {** }}$ & 1 & $0,185^{* *}$ & 0,023 \\
\hline SIZE & 0,029 & $0,255^{\text {** }}$ & $0,366^{* *}$ & $0,310^{* *}$ & $0,377^{\text {** }}$ & 0,059 & $-0,247^{\text {** }}$ & $-0,049$ & $0,113^{*}$ & $0,591^{* *}$ & $-0,126^{*}$ & $-0,158^{* *}$ & $-0,058$ & $0,185^{\text {** }}$ & 1 & 0,078 \\
\hline $\mathrm{MB}$ & $0,264^{* *}$ & $0,134^{*}$ & 0,089 & 0,040 & 0,074 & 0,039 & 0,032 & 0,050 & $-0,043$ & 0,016 & $-0,120$ & $-0,022$ & 0,072 & 0,023 & 0,078 & 1 \\
\hline
\end{tabular}

** Signifikan pada $\alpha=1 \%$ (2-tailed) $\quad *$ Signifikan pada $\alpha=5 \%$ (2-tailed)

Tabel 5. Korelasi Pearson (Klien Big 4)

\begin{tabular}{|c|c|c|c|c|c|c|c|c|c|c|c|c|c|c|c|c|}
\hline & $\mathrm{ACC}$ & LN_JR & LN_JA & LN_JK & LN_JP & CFO & CFO_V & DEBT & S_GR & S_VOL & LOSS & LAG_L & T_AP & T_KAP & SIZE & MB \\
\hline ACC & 1 & $-0,188^{*}$ & 0,148 & 0,076 & 0,031 & $0,153^{*}$ & $0,172^{*}$ & $-0,268^{* *}$ & 0,096 & 0,036 & 0,008 & 0,072 & $-0,016$ & $0,197^{*}$ & 0,004 & $0,247^{\text {*k }}$ \\
\hline LN_JR & $-0,188^{*}$ & 1 & $-0,018$ & 0,033 & $-0,413^{* *}$ & $-0,071$ & 0,024 & 0,012 & 0,066 & $-0,067$ & 0,039 & $-0,031$ & $-0,200^{*}$ & $-0,511^{\text {** }}$ & $-0,167^{\star}$ & $-0,205^{*}$ \\
\hline LN_JA & 0,148 & $-0,018$ & 1 & $0,909^{* *}$ & 0,000 & 0,021 & 0,033 & 0,027 & 0,041 & 0,037 & $-0,085$ & 0,029 & $0,337^{\text {tk }}$ & $0,320^{* *}$ & 0,057 & $-0,049$ \\
\hline LN_JK & 0,076 & 0,033 & $0,909^{* *}$ & 1 & $0,184^{*}$ & $-0,037$ & 0,031 & 0,115 & 0,026 & $-0,042$ & $-0,038$ & 0,043 & $0,300^{* *}$ & 0,120 & 0,004 & $-0,122$ \\
\hline LN_JP & 0,031 & $-0,413^{\star *}$ & 0,000 & $0,184^{*}$ & 1 & 0,034 & $-0,027$ & $0,153^{*}$ & 0,003 & 0,023 & 0,114 & 0,008 & $0,223^{\text {** }}$ & 0,085 & 0,091 & 0,001 \\
\hline $\mathrm{CFO}$ & $0,153^{*}$ & $-0,071$ & 0,021 & $-0,037$ & 0,034 & 1 & $-0,043$ & $-0,068$ & 0,008 & 0,070 & $-0,055$ & 0,047 & 0,122 & 0,109 & 0,034 & 0,096 \\
\hline CFO_VOL & 0 & 0,024 & 0,033 & 0,031 & $-0,027$ & $-0,043$ & 1 & 0,056 & 0,000 & $-0,150$ & 0,063 & 0,096 & $-0,035$ & $-0,001$ & $-0,371^{* *}$ & $-0,108$ \\
\hline DEBT & $-0,268^{* *}$ & 0,012 & 0,027 & 0,115 & $0,153^{*}$ & $-0,068$ & 0,056 & 1 & 0,020 & 0,031 & $0,418^{* *}$ & $0,348^{* *}$ & 0,107 & $-0,082$ & 0,046 & 0,037 \\
\hline S_GR & 0 , & 0,066 & 0,041 & 0,026 & 0,003 & 0,008 & 0,000 & 0,020 & 1 & $0,212^{* *}$ & $0,251^{* *}$ & 0,022 & 0,008 & $-0,042$ & 0,130 & $-0,098$ \\
\hline S_VOL & 0 , & $-0,067$ & 0,037 & $-0,042$ & 0,023 & 0,070 & $-0,150$ & 0,031 & $0,212^{* *}$ & 1 & $-0,044$ & $-0,044$ & $-0,020$ & 0,114 & $0,619^{* *}$ & 0,123 \\
\hline LOSS & 0,008 & 0,039 & $-0,085$ & $-0,038$ & 0,114 & $-0,055$ & 0,063 & $0,418^{* *}$ & $0,251^{* *}$ & $-0,044$ & 1 & $0,564^{* *}$ & 0,065 & $-0,070$ & $-0,091$ & $-0,141$ \\
\hline L_LOSS & 0,072 & $-0,031$ & 0,029 & 0,043 & 0,008 & 0,047 & 0,096 & $0,348^{* *}$ & 0,022 & $-0,044$ & $0,564^{* *}$ & 1 & 0,038 & $-0,054$ & $-0,120$ & $-0,032$ \\
\hline T_AP & $-0,016$ & $-0,200^{*}$ & $0,337^{\text {** }}$ & $0,300^{* *}$ & $0,223^{* *}$ & 0,122 & $-0,035$ & 0,107 & 0,008 & $-0,020$ & 0,065 & 0,038 & 1 & $0,417^{\text {** }}$ & $-0,046$ & 0,059 \\
\hline T_KAP & $0,197^{*}$ & $-0,511^{* *}$ & $0,320^{* *}$ & 0,120 & 0,085 & 0,109 & $-0,001$ & $-0,082$ & $-0,042$ & 0,114 & $-0,070$ & $-0,054$ & $0,417^{\text {*k }}$ & 1 & 0,158 & 0,167 \\
\hline SIZE & 0,004 & $-0,167^{*}$ & 0,057 & 0,004 & 0,091 & 0,034 & $-0,371^{* *}$ & 0,046 & 0,130 & $0,619^{* *}$ & $-0,091$ & $-0,120$ & $-0,046$ & 0,158 & 1 & 0,063 \\
\hline $\mathrm{MB}$ & $0,247^{* *}$ & $-0,205^{*}$ & $-0,049$ & $-0,122$ & 0,001 & 0,096 & $-0,108$ & 0,037 & $-0,098$ & 0,123 & $-0,141$ & $-0,032$ & 0,059 & 0,167 & 0,063 & 1 \\
\hline
\end{tabular}


Tabel 6. Korelasi Pearson (Klien Non Big 4)

\begin{tabular}{|c|c|c|c|c|c|c|c|c|c|c|c|c|c|c|c|c|}
\hline & ACC & LN_JR & LN_JA & LN_JK & LN_JP & CFO & CFO_V & DEBT & S_GR & S_VOL & LOSS & LAG_L & T_AP & T_KAP & SIZE & $\overline{M B}$ \\
\hline ACC & 1 & 0,015 & $-0,231^{* *}$ & $-0,178^{*}$ & $-0,097$ & $-0,021$ & 0,032 & $0,224^{* *}$ & 0,099 & $-0,105$ & $0,346^{* *}$ & $0,285^{* *}$ & 0,053 & $-0,089$ & $-0,189^{*}$ & 0,142 \\
\hline LN_JR & 0,015 & 1 & $0,705^{* *}$ & $0,597^{* *}$ & $0,436^{* *}$ & 0,048 & 0,020 & $-0,083$ & 0,001 & $-0,163^{*}$ & 0,072 & 0,024 & $-0,003$ & $-0,044$ & $-0,047$ & 0,179 \\
\hline LN_JA & $-0,231^{* *}$ & $0,705^{* *}$ & 1 & $0,914^{* *}$ & $0,704^{* *}$ & 0,083 & $-0,143$ & $-0,186^{*}$ & $-0,010$ & $0,153^{*}$ & $-0,270^{* *}$ & $-0,234^{* *}$ & $-0,009$ & $0,240^{* *}$ & $0,217^{* *}$ & 0,062 \\
\hline LN_JK & -0 , & $0,597^{\text {** }}$ & $0,914^{* *}$ & 1 & $0,674^{* *}$ & 0,097 & $-0,124$ & $-0,189^{*}$ & $-0,026$ & 0,078 & $-0,281^{\text {** }}$ & $-0,204^{* *}$ & $-0,007$ & $0,211^{*}$ & $0,149^{*}$ & 0,020 \\
\hline LN_JP & -0 & $0,436^{* *}$ & $0,704^{* *}$ & $0,674^{* *}$ & 1 & 0,029 & $-0,115$ & $-0,137$ & $-0,054$ & 0,148 & $-0,158^{*}$ & $-0,276^{* *}$ & 0,061 & $0,265^{* *}$ & $0,203^{\text {** }}$ & $-0,017$ \\
\hline $\mathrm{CFO}$ & $-0,021$ & 0,048 & 0,083 & 0,097 & 0,029 & 1 & $-0,143$ & 0,048 & 0,046 & 0,046 & 0,054 & 0,079 & $-0,151$ & $-0,180^{*}$ & 0,000 & $-0,074$ \\
\hline CFO_VOL & 0,032 & 0,020 & $-0,143$ & $-0,124$ & $-0,115$ & $-0,143$ & 1 & $0,149^{*}$ & $-0,012$ & $-0,153^{*}$ & 0,006 & $-0,035$ & 0,152 & 0,003 & $-0,119$ & $0,195^{*}$ \\
\hline DEBT & $0,224^{* *}$ & $-0,083$ & $-0,186^{*}$ & $-0,189^{*}$ & $-0,137$ & 0,048 & $0,149^{*}$ & 1 & 0,078 & $-0,025$ & $0,274^{* *}$ & $0,292^{* *}$ & $-0,055$ & $-0,166^{*}$ & 0,008 & 0,079 \\
\hline S_GR & 0,099 & 0,001 & $-0,010$ & $-0,026$ & $-0,054$ & 0,046 & $-0,012$ & 0,078 & 1 & $-0,011$ & $-0,173^{*}$ & 0,013 & $-0,028$ & 0,139 & 0,051 & 0,036 \\
\hline S_VOL & -0 & $-0,163^{*}$ & $0,153^{*}$ & 0,078 & 0,148 & 0,046 & $-0,153^{*}$ & $-0,025$ & $-0,011$ & 1 & 0,013 & $-0,093$ & $-0,051$ & $0,346^{* *}$ & $0,598^{* *}$ & $-0,172$ \\
\hline LOSS & $0,346^{* *}$ & 0,072 & $-0,270^{* *}$ & $-0,281^{\text {*k }}$ & $-0,158^{*}$ & 0,054 & 0,006 & $0,274^{* *}$ & $-0,173^{*}$ & 0,013 & 1 & $0,579^{* *}$ & $-0,027$ & $-0,218^{* *}$ & $-0,098$ & $-0,100$ \\
\hline L_LOSS & $0,285^{* *}$ & 0,024 & $-0,234^{* *}$ & $-0,204^{* *}$ & $-0,276^{* *}$ & 0,079 & $-0,035$ & $0,292^{* *}$ & 0,013 & $-0,093$ & $0,579^{* *}$ & 1 & $-0,094$ & $-0,156$ & $-0,132$ & $-0,006$ \\
\hline T_AP & 0 & $-0,003$ & $-0,009$ & $-0,007$ & 0,061 & $-0,151$ & 0,152 & $-0,055$ & $-0,028$ & $-0,051$ & $-0,027$ & $-0,094$ & 1 & $0,398^{* *}$ & $-0,073$ & 0,090 \\
\hline T_KAP & $-0,089$ & $-0,044$ & $0,240^{* *}$ & $0,211^{*}$ & $0,265^{* *}$ & $-0,180^{*}$ & 0,003 & $-0,166^{*}$ & 0,139 & $0,346^{* *}$ & $-0,218^{* *}$ & $-0,156$ & $0,398^{* *}$ & 1 & $0,269^{* *}$ & $-0,065$ \\
\hline SIZE & $-0,189^{*}$ & $-0,047$ & $0,217^{* *}$ & $0,149^{*}$ & $0,203^{* *}$ & 0,000 & $-0,119$ & 0,008 & 0,051 & $0,598^{* *}$ & $-0,098$ & $-0,132$ & $-0,073$ & $0,269^{* *}$ & 1 & $-0,102$ \\
\hline $\mathrm{MB}$ & 0,142 & 0,179 & 0,062 & 0,020 & $-0,017$ & $-0,074$ & $0,195^{*}$ & 0,079 & 0,036 & $-0,172$ & $-0,100$ & $-0,006$ & 0,090 & $-0,065$ & $-0,102$ & 1 \\
\hline
\end{tabular}

Tabel 7. Hasil Pengujian Empiris

\begin{tabular}{|c|c|c|c|c|c|c|c|c|c|c|}
\hline \multirow[t]{2}{*}{ Variabel } & \multirow{2}{*}{$\begin{array}{l}\text { Pred. } \\
\text { Sign }\end{array}$} & \multicolumn{3}{|c|}{$\begin{array}{c}\text { Big } 4 \text { dan Non-Big } 4 \\
(n=348)\end{array}$} & \multicolumn{3}{|c|}{$\begin{array}{c}\text { Big } 4 \\
(n=166) \\
\end{array}$} & \multicolumn{3}{|c|}{$\begin{array}{c}\text { Non-Big } 4 \\
(\mathrm{n}=182)\end{array}$} \\
\hline & & Coef. & t-stat & Prob. & Coef. & t-stat & Prob. & Coef. & t-stat & Prob. \\
\hline $\mathrm{C}$ & & $-0,075$ & $-0,437$ & 0,331 & $-0,058$ & $-0,200$ & 0,421 & 0,012 & 0,105 & 0,458 \\
\hline LN_JR & - & $-0,009$ & $-0,575$ & 0,283 & $-0,021$ & $-0,463$ & 0,322 & $-0,002$ & $-0,113$ & 0,455 \\
\hline LN_JA & - & 0,023 & 2,033 & $0,022^{*}$ & 0,021 & 1,363 & $0,088^{* * *}$ & 0,009 & 0,961 & 0,170 \\
\hline $\mathrm{CFO}$ & - & 0,077 & 0,791 & 0,215 & 0,169 & 0,924 & 0,179 & $-0,070$ & $-1,887$ & $0,031^{*}$ \\
\hline CFO_VOL & + & 0,254 & 1,991 & $0,024^{*}$ & 0,455 & 2,213 & $0,015^{*}$ & 0,051 & 0,909 & 0,183 \\
\hline DEBT & + & $-0,169$ & $-5,400$ & $0,000^{*}$ & $-0,236$ & $-5,077$ & $0,000^{*}$ & $-0,052$ & $-2,015$ & $0,023^{*}$ \\
\hline SAL_GR & + & 0,001 & 0,372 & 0,355 & 0,000 & 0,066 & 0,474 & 0,029 & 4,894 & $0,001^{*}$ \\
\hline SAL_VOL & + & 0,000 & 0,465 & 0,321 & 0,000 & 0,394 & 0,347 & 0,000 & 0,008 & 0,497 \\
\hline LOSS & - & 0,079 & 1,667 & $0,048^{*}$ & 0,134 & 1,464 & $0,073^{* *}$ & 0,045 & 1,131 & 0,131 \\
\hline L_LOSS & - & 0,046 & 1,143 & 0,127 & 0,091 & 1,214 & 0,114 & $-0,019$ & $-0,874$ & 0,192 \\
\hline TEN_AP & - & $-0,012$ & $-1,386$ & $0,084^{* * *}$ & $-0,019$ & $-1,016$ & 0,156 & 0,000 & 0,000 & 0,499 \\
\hline TEN_KAP & - & 0,010 & 1,922 & $0,028^{*}$ & 0,016 & 1,799 & $0,038^{*}$ & $-0,003$ & $-1,044$ & 0,150 \\
\hline SIZE & + & 0,006 & 0,680 & 0,249 & 0,007 & 0,528 & 0,299 & 0,002 & 0,360 & 0,360 \\
\hline MB & + & 0,022 & 2,473 & $0,007^{*}$ & 0,038 & 2,525 & $0,007^{*}$ & 0,001 & 0,181 & 0,429 \\
\hline \multicolumn{2}{|c|}{ Adj. $R^{2}$} & \multicolumn{3}{|c|}{0,245} & \multicolumn{3}{|c|}{0,310} & \multicolumn{3}{|c|}{0,064} \\
\hline \multicolumn{2}{|l|}{ F } & \multicolumn{3}{|c|}{6,119} & \multicolumn{3}{|c|}{4,556} & \multicolumn{3}{|c|}{1,531} \\
\hline \multicolumn{2}{|c|}{ F statistic } & \multicolumn{3}{|c|}{$0,000^{*}$} & \multicolumn{3}{|c|}{$0,000^{*}$} & \multicolumn{3}{|c|}{0,122} \\
\hline
\end{tabular}

LN_JR merupakan ukuran KAP yang diukur dengan menggunakan logaritma natural dari banyaknya rekan yang dimiliki oleh KAP, LN_JA merupakan ukuran KAP yang diukur dengan menggunakan logaritma natural dari banyaknya auditor yang dimiliki oleh KAP, CFO merupakan arus kas operasi dibagi dengan total aset tahun sebelumnya, CFO_VOL merupakan standar deviasi dari CFO selama tiga tahun, DEBT merupakan jumlah utang perusahaan dibagi dengan total aset, SAL_GR merupakan tingkat pertumbuhan penjualan perusahaan per tahun, SAL_VOL merupakan standar deviasi dari penjualan selama tiga tahun; LOSS merupakan variabel dummy yang diberikan nilai 1 untuk perusahaan yang memiliki laba operasi negatif dan 0 untuk lainnya; LAG_LOSS merupakan variabel dummy yang diberikan nilai 1 untuk perusahaan yang memiliki laba operasi negatif pada tahun sebelumnya dan 0 untuk lainnya; TENURE_AP merupakan lamanya periode audit oleh akuntan publik; TENURE_KAP merupakan lamanya periode audit oleh akuntan publik; SIZE merupakan ukuran perusahaan yang diukur dengan nilai natural logaritma dari total aset; MB merupakan nilai natural logaritma dari rasio market value of equity to its book value equity.

* Signifikan pada $\alpha=5 \%$

** Signifikan pada $\alpha=10 \%$

Untuk proksi ukuran KAP yang lainnya, yaitu LN_JA memiliki koefisien yang positif dan signifikan ketika menggunakan seluruh sampel. Hasil tersebut juga tidak sesuai dengan prediksi dan penelitian Francis \& Yu (2009) yang menyebutkan ukuran KAP yang diproksikan dengan jumlah pendapatan KAP memiliki koefisien yang negatif dan signifikan. Hal ini kemungkinan terjadi karena rendahnya tingkat kompetisi yang dihadapi oleh KAP besar yang membuat kualitas audit yang dihasilkan KAP besar mengalami penurunan. Ketergantungan pasar akan keunggulan KAP besar membuat KAP kecil sulit berkompetisi. Dengan kondisi memiliki banyak klien, menjadikan KAP besar merasa sudah berada pada area yang aman dan cenderung kurang memperhatikan kualitas auditnya sehingga memungkinkan penurunan kualitas audit.

Koefisien CFO positif dan tidak signifikan, tidak sesuai dengan prediksi. Namun hasil ini 
konsisten dengan Fajri (2008). Hal ini kemungkinan terjadi karena manajemen laba tidak hanya terbatas pada aktivitas meninggikan laba, tapi bisa juga dilakukan dengan cara mengecilkan laba (income smoothing) dengan tujuan untuk menjaga kestabilan pergerakan laba. Fajri (2008) mengatakan dengan adanya insentif yang sama besar bagi perusahaan untuk melakukan manajemen laba baik pada saat arus kas operasi tinggi maupun pada saat arus kas operasi rendah, membuat tidak adanya pengaruh antara arus kas operasi dan akrual diskresioner. Untuk variabel kontrol SIZE tidak berpengaruh terhadap akrual. Hasil ini konsisten dengan penelitian Fajri (2008). Hasil negatif yang signifikan pada ACCRUALS dan DEBT berlawanan dengan prediksi. Namun hasil ini sesuai dengan penelitian Jeong dan Rho (2004) dalam Pratiwi (2010) yang menyebutkan bahwa perusahaan yang bermasalah tidak selalu meningkatkan akrual diskresionernya, tetapi justru dapat menurunkan akrual diskresionernya karena kreditur sudah memahami bahwa perusahaan sedang mengalami kesulitan keuangan.

Berdasarkan Tabel 8, nilai Nagelkerhe RSquare pada model penelitian dengan menggunakan seluruh sampel adalah 0,385. Berikutnya untuk kelompok sampel klien KAP Big 4, diperoleh nilai Nagelkerhe R-Square sebesar 0,674 yang berarti bahwa seluruh variabel bebas mampu menjelaskan varians penerbitan laporan audit going concern sebesar $67,4 \%$ dan sisanya sebesar $32,6 \%$ dijelaskan oleh faktor lain. Begitu juga dengan kelompok sampel klien KAP Non-Big 4 yang memperoleh nilai Nagelkerhe R-Square sebesar 0,448 . Artinya hampir sebesar $42,4 \%$ variabel terikat dapat dijelaskan oleh variabel bebas dan kontrol yang ada.

Untuk pengujian seluruh sampel, pengaruh dari ukuran KAP tidak signifikan. Hasil ini tidak sesuai dengan hasil penelitian Francis \& Yu (2010) yang menemukan pengaruh positif yang signifikan antara ukuran KAP Big 4 dengan penerbitan laporan audit going concern. Hasil yang berbeda ditunjukkan ketika sampel dikelompokkan ke dalam kelompok sampel KAP Non-Big 4, koefisien dari LN_JR terlihat positif dan signifikan, sehingga hasil ini konsisten dengan penelitian Francis \& Yu (2010). Artinya pada kelompok sampel klien KAP Non-Big 4, ukuran KAP yang lebih besar menerbitkan laporan audit going concern yang lebih banyak. Jadi dengan jumlah rekan yang lebih banyak, tenaga audit yang lebih profesional KAP tersebut pun juga semakin banyak. Dengan banyaknya tenaga audit yang lebih profesional, akan semakin baik kemampuan KAP dalam mendeteksi masalah kelangsungan hidup suatu perusahaan dan menghasilkan penerbitan laporan audit.

Tabel 8. Hasil Pengujian Empiris

\begin{tabular}{|c|c|c|c|c|c|c|c|c|c|c|}
\hline \multirow[t]{2}{*}{ Variabel } & \multirow{2}{*}{$\begin{array}{l}\text { Pred. } \\
\text { Sign }\end{array}$} & \multicolumn{3}{|c|}{$\begin{array}{c}\text { Big } 4 \text { dan Non-Big } 4 \\
(\mathrm{n}=348)\end{array}$} & \multicolumn{3}{|c|}{$\begin{array}{c}\text { Big } 4 \\
(n=166) \\
\end{array}$} & \multicolumn{3}{|c|}{$\begin{array}{c}\text { Non-Big } 4 \\
(n=182)\end{array}$} \\
\hline & & Coef. & t-stat & Prob. & Coef. & t-stat & Prob. & Coef. & t-stat & Prob. \\
\hline LN_JR & + & 0,137 & 0,066 & 0,399 & $-5,777$ & 1,434 & 0,116 & 2,017 & 4,675 & $0,016^{*}$ \\
\hline LN_JA & + & $-0,445$ & 2,336 & $0,063 * *$ & 0,046 & 0,005 & 0,473 & $-0,826$ & 3,255 & $0,036^{*}$ \\
\hline CASH & - & $-1,306$ & 0,174 & 0,339 & $-6,200$ & 0,372 & 0,271 & $-0,956$ & 0,062 & 0,402 \\
\hline DEBT & + & 2,532 & 3,947 & $0,024^{*}$ & 3,998 & 1,994 & $0,079 * *$ & 0,130 & 0,005 & 0,471 \\
\hline SAL_VOL & + & 0,000 & 4,560 & $0,017^{*}$ & 0,000 & 3,528 & $0,03^{*}$ & 0,000 & 2,285 & $0,066^{* *}$ \\
\hline LOSS & + & 2,705 & 7,790 & $0,003^{*}$ & 3,541 & 5,897 & $0,008^{*}$ & 3,442 & 3,551 & $0,030^{*}$ \\
\hline L_LOSS & + & 1,697 & 5,610 & $0,009^{*}$ & 1,704 & 1,257 & 0,131 & 2,379 & 4,464 & $0,018^{*}$ \\
\hline TEN_AP & + & 0,260 & 0,953 & 0,165 & 1,570 & 2,694 & 0,051 & 0,109 & 0,102 & 0,375 \\
\hline TEN_KAP & + & 0,259 & 2,360 & $0,062 * *$ & $-1,507$ & 2,127 & $0,073^{* *}$ & 0,372 & 2,648 & $0,052^{* *}$ \\
\hline SIZE & - & $-0,209$ & 0,862 & 0,177 & $-1,619$ & 3,437 & $0,032^{*}$ & 0,276 & 0,488 & 0,243 \\
\hline $\mathrm{MB}$ & + & 0,193 & 0,825 & 0,182 & 0,657 & 1,116 & 0,146 & 0,592 & 3,208 & $0,037^{*}$ \\
\hline $\mathrm{C}$ & & 1,581 & 0,135 & 0,357 & 43,131 & 2,286 & $0,066^{* *}$ & $-8,175$ & 1,131 & 0,144 \\
\hline \multicolumn{2}{|c|}{$-2 \mathrm{LL}$} & \multicolumn{3}{|c|}{141,416} & \multicolumn{3}{|c|}{27,179} & \multicolumn{3}{|c|}{81,550} \\
\hline \multirow{2}{*}{\multicolumn{2}{|c|}{$\begin{array}{l}\text { Cox \& Snell R Square } \\
\text { Nagelkerke R Square }\end{array}$}} & \multicolumn{3}{|c|}{0,237} & \multicolumn{3}{|c|}{0,344} & \multicolumn{3}{|c|}{0,287} \\
\hline & & \multicolumn{3}{|c|}{0,385} & \multicolumn{3}{|c|}{0,674} & \multicolumn{3}{|c|}{0,424} \\
\hline
\end{tabular}

LN_JR merupakan ukuran KAP yang diukur dengan menggunakan logaritma natural dari banyaknya rekan yang dimiliki oleh KAP, LN_JA merupakan ukuran KAP yang diukur dengan menggunakan logaritma natural dari banyaknya auditor yang dimiliki oleh KAP, CASH merupakan jumlah kas dan setara kas yang dimiliki oleh perusahaan dibagi dengan total aset, DEBT merupakan jumlah utang perusahaan dibagi dengan total aset, SAL_VOL merupakan standar deviasi dari penjualan selama tiga tahun; LOSS merupakan variabel dummy yang diberikan nilai 1 untuk perusahaan yang memiliki laba operasi negatif dan 0 untuk lainnya; LAG_LOSS merupakan variabel dummy yang diberikan nilai 1 untuk perusahaan yang memiliki laba operasi negatif pada tahun sebelumnya dan 0 untuk lainnya; TENURE_AP merupakan lamanya periode audit oleh akuntan publik; TENURE_KAP merupakan lamanya periode audit oleh akuntan publik; SIZE merupakan ukuran perusahaan yang diukur dengan nilai natural logaritma dari total aset; MB merupakan nilai natural logaritma dari rasio market value of equity to its book value equity.

* Signifikan pada $a=5 \%$

** Signifikan pada $\alpha=10 \%$ 
Pada variabel lain, LN_JA yang juga merupakan proksi ukuran KAP, diperoleh hasil yang tidak signifikan. Hal ini konsisten dengan penelitian Tamba (2009) yang mendapatkan hasil serupa ketika menguji pengaruh kualitas audit terhadap penerimaan going concern. Artinya ukuran KAP yang lebih besar tidak lebih banyak menerbitkan laporan audit going concern dibanding KAP yang lebih kecil.

Manajer perusahaan yang rasional tidak akan memilih auditor yang berkualitas tinggi dan membayar fee yang tinggi apabila kondisi perusahaan sedang tidak baik. Hal ini disebabkan karena ada anggapan bahwa auditor yang berkualitas tinggi akan mampu mendeteksi kondisi perusahaan yang tidak baik dan menyampaikannya kepada publik. Jadi, perusahaan yang menggunakan jasa KAP yang lebih besar biasanya adalah perusahaan yang memiliki kondisi yang baik, sehingga cenderung mendapatkan pendapat wajar tanpa pengecualian, sementara perusahaan yang kondisinya sedang tidak baik lebih banyak menggunakan KAP yang lebih kecil dengan harapan KAP tidak dapat mendeteksi kondisi perusahaan yang tidak baik.

Variabel kontrol CASH tidak signifikan, baik untuk kelompok sampel klien KAP Big 4 maupun KAP Non-Big 4. Kondisi likuiditas perusahaan tidak mempengaruhi keputusan auditor dalam mengeluarkan opini audit going concern. DEBT memiliki pengaruh yang signifikan positif terhadap penerbitan laporan audit going concern. Semakin tinggi utang perusahaan akan menunjukkan kondisi keuangan perusahaan yang kurang baik, hal tersebut mengakibatkan kemungkinan penerbitan laporan audit going concern yang cukup besar. Hasil untuk variabel LOSS konsisten dengan Francis \& Yu (2009), yaitu berpengaruh negatif signifikan. Variabel kontrol lainnya TENURE_AP, TENURE_KAP, dan SIZE tidak berpengaruh signifikan. Variabel kontrol terakhir adalah market to book value (MB). Hasil koefisien untuk variabel kontrol ini adalah positif dan signifikan hanya untuk kelompok sampel klien KAP Non-Big 4, sedangkan untuk kelompok sampel lainnya tidak signifikan.

Hasil pengujian atas hipotesis pertama dan kedua tidak memberikan bukti yang mendukung hipotesis. Oleh karena itu dilakukan pengujian tambahan. Pada model utama untuk hipotesis pertama digunakan jumlah rekan dan jumlah auditor sebagai proksi dari ukuran KAP karena berdasarkan hasil pengujian multikolinearitas, kombinasi dua variabel tersebut menghasilkan nilai rata-rata adjusted $\mathrm{R}^{2}$ yang paling tinggi. Dalam pengujian tambahan, diuji dua kombinasi ukuran KAP lainnya yaitu, kombinasi antara jumlah rekan dengan jumlah klien (kombinasi 2) serta kombinasi antara jumlah rekan dengan jumlah pendapatan (kombinasi 3).

Hasil pengujian dari kombinasi 2, memperlihatkan hal yang sama dengan hasil pengujian pada model utama, yaitu tidak terdapat hubungan yang signifikan antara variabel-variabel yang dijadikan proksi ukuran auditor dengan jumlah akrual perusahaan. Begitu juga dengan kombinasi 3 yang menunjukkan hasil yang secara kualitatif yang tidak berbeda dengan pengujian kombinasi 1 dan 2. Tidak terdapat perbedaan signifikan ketika ukuran auditor diukur dengan jumlah rekan, jumlah auditor, jumlah klien ataupun jumlah pendapatan KAP tersebut. Hasil dari seluruh pengujian menunjukkan tidak terdapat hubungan antara ukuran KAP dengan kualitas audit yang diukur melalui kualitas akrual.

Untuk model 2 juga dilakukan uji tambahan, dengan menggunakan kombinasi yang sama dengan model 1 . Hasilnya tidak terdapat perbedaan antara hasil model utama (kombinasi 1) dengan hasil uji kombinasi 2 dan kombinasi 3. Semua hasilnya menunjukkan tidak terdapat pengaruh yang signifikan ukuran KAP terhadap penerbitan laporan audit going concern yang dijadikan proksi kualitas audit.

\section{KESIMPULAN}

Dari hasil analisis dan pembahasan di atas, diperoleh beberapa kesimpulan bahwa ukuran KAP tidak berpengaruh signifikan terhadap kualitas audit yang diukur dengan nilai akrual dan ukuran KAP juga tidak memiliki pengaruh terhadap probabilita penerbitan laporan audit going concern. Artinya bahwa tidak terdapat perbedaan kualitas akrual bagi perusahaan yang diaudit oleh KAP yang besar, baik itu KAP Big 4 maupun KAP Non-Big 4. Selain itu, penerbitan laporan audit going concern pada perusahaan yang diaudit oleh KAP yang besar juga dapat dikatakan seragam dengan KAP yang kecil. Secara keseluruhan disimpulkan bahwa hasil pengujian belum dapat memberi bukti yang konsisten dengan penelitian sebelumnya. Pengujian sensitifitas atas pengukuran ukuran KAP juga belum memberikan bukti bahwa KAP yang lebih besar akan menghasilkan kualitas audit yang lebih baik.

Hal ini kemungkinan besar terjadi karena terdapat faktor-faktor yang lebih mempengaruhi kualitas audit selain faktor ukuran KAP. Faktor tersebut adalah kompetensi dan independensi. Apabila ukuran KAP yang besar tidak dibarengi dengan kompetensi yang tinggi dari auditornya, kemampuan mendeteksi manajemen laba serta kesangsian kelangsungan usaha pun akan rendah. 
Akibatnya kualitas akrual juga akan rendah. Begitu juga dengan independensi, KAP dengan ukuran besar yang auditornya memiliki kompetensi yang tinggi akan membantu perusahaan dalam melakukan manajemen laba apabila auditor tersebut kurang memiliki independensi.

Dalam melakukan penelitian ini, terdapat beberapa keterbatasan yang dihadapi, antara lain adalah pengukuran kualitas audit hanya menggunakan dua pengukuran saja. Kemungkinan terdapat pengukuran kuantitatif lain yang lebih representatif untuk menjelaskan kualitas audit. Model akrual diskresioner yang digunakan pun tidak dapat dipastikan mampu memisahkan komponen diskresioner dan non diskresioner dengan tepat. Penelitian selanjutnya dapat menggunakan pengukuran kualitas audit lain seperti kualitas laba yang diukur melalui earning response coefficients (ERC). Kemungkinan masih banyak faktor-faktor lain yang belum dimasukkan ke dalam model yang mengakibatkan penggunaan model yang kurang tepat untuk kelompok sampel klien KAP Non-Big 4. Pengukuran ukuran KAP hanya melalui empat jenis pengukuran yaitu jumlah rekan, jumlah auditor, jumlah klien, dan jumlah total pendapatan KAP. Pengukuran ukuran KAP disarankan mencoba menggunakan ukuran jumlah pendapatan non-audit dibandingkan pendapatan audit dari KAP karena ukuran tersebut diduga akan mempengaruhi kualitas audit.

\section{DAFTAR PUSTAKA}

Arens, A.A., Elder, R.J., \& Beasley, M.S. (2009). Auditing and Assurance Services, An Integrated Approach. (13 $3^{\text {th }}$ ed.)New Jersey: Pearson Education, Inc.

Alim, M.N., Hapsari, T., \& Purwanti, L. (2007). Pengaruh Kompetensi dan Independensi Terhadap Kualitas Audit dengan Etika Auditor Sebagai Variabel Moderasi. Simposium Nasional Akuntansi X, Makassar.

Carcello, J., Hermanson, R. \& McGrath, N. (1992). Audit Quality Attributes: The Perception of Audit Partners, Preparers, and Financial Statements Users. Auditing: A Journal of Practice \& Theory, 11, 1-15.

Carcello, J., \& Neal, T. (2003). Audit Committee Characteristics and Auditor Dismissals Following 'New' Goingconcern Reports. The Accounting Review, 95-117.

Choi, J.H., Kim, F., Kim, J.B. \& Zang, Y.S. (2010). Audit Office Size, Audit Quality and Audit Pricing. Auditing: A Journal of Practice \& Theory, 29(1), 73-97.
Dahlan, M. (2009). Analisis Hubungan Antara Kualitas Audit Dengan Diskresioner Akrual dan Kebebasan Auditor. Working paper: Universitas Padjajaran.

Ferguson, A., Francis, J.R., \& Stokes, D.J. (2003). The Effect of Firm Wide and Office Level Industry Expertise on Audit Pricing. The Accounting Review, 78, 429-448.

Fajri, T.N. (2008). Analisis Pengaruh Praktek Rotasi Audit Terhadap Kualitas Audit: Studi Empiris Perusahaan Manufaktur di Indonesia. Skripsi, Universitas Indonesia.

Francis, J.R., Stokes, D.J., \& Anderson, D.J. (1999). City Markets as Unit of Analysis In Audit Research and The Re-examination of Big 6 Market Shares. Abacus, 80, 113-136.

Francis, J.R., \& Yu, D.M. (2009). Big 4 Office Size and Audit Quality. The Accounting Review, 84, 1521-1552.

Hermawan, A.A. (2009). Pengaruh Efektivititas Dewan Komisaris dan Komite Audit, Kepemilikan Oleh Keluarga dan Peran Monitoring Bank Terhadap Kandungan Informasi Laba. Disertasi, Universitas Indonesia.

Herusetya, A. (2009), "Pengaruh Ukuran Auditor dan Spesialisasi Auditor Terhadap Kualitas Laba", Jurnal Akuntansi dan Keuangan Indonesia 6(1), hal. 46-70.

Jang, L., Sugiarto. B., \& Siagian, D. (2007). Faktorfaktor yang Mempengaruhi Kualitas Laba pada Perusahaan Manufaktur di BEJ. ISSN, 6, 1412-0240.

Komalasari, A.A. (2004). Analisis Pengaruh Kualitas Auditor dan Proxi Going Concern Terhadap Opini Auditor. Jurnal Akuntansi dan Keuangan, 9(2), 1-16.

Novita, E.I. (2009). Pengaruh Ukuran Kantor Akuntan Publik terhadap Kualitas Audit pada Perusahaan Manufaktur yang Listing di BEI Tahun 2005-2007. Skripsi, Universitas Airlangga.

Pardede, E.B. (2010). Analisis Faktor-faktor yang Mempengaruhi Kualitas Audit: Studi Empiris Perusahaan Manufaktur 2005-2008. Skripsi, Universitas Indonesia.

Perdana, G.S. (2009). Analisis Pengaruh Ukuran Perusahaan, Opini Audit, Ukuran KAP dan Jenis Industri Terhadap Audit Lag pada Perusahaan Publik yang Terdaftar di Bursa Efek Indonesia untuk Industri Manufaktur dan Perbankan. Skripsi, Universitas Indonesia. 
Pratiwi, S.S. (2010). Pengaruh Auditor Big 4 dan Audit Tenure Terhadap Kualitas Audit. Skripsi. Universitas Indonesia.

Rudyawan, A.P., \& Badera, I.D.N. (2008). Opini Audit Going Concern: Kajian Berdasarkan Model Prediksi Kebangkrutan, Pertumbuhan Perusahaan, Leverage dan Reputasi Auditor. Universitas Udayana.

Riyatno (2007). Pengaruh Ukuran Kantor Akuntan Publik Terhadap Earnings Response Coefficients. Jurnal Keuangan dan Bisnis, 5, 148-162.

Solikah, B. (2007). Pengaruh Kondisi Keuangan Perusahaan, Pertumbuhan Perusahaan, dan Opini Audit Tahun Sebelumnya Terhadap Opini Audit Going Concern. Skripsi, Universitas Negeri Semarang.

Tamba, R.U.B. (2009). Pengaruh Debt Default, Kualitas Audit dan Opini Audit Terhadap Penerimaan Opini Going Concern pada Per- usahaan Manufaktur yang Terdaftar di Bursa Efek Indonesia. Skripsi, Universitas Sumatera Utara.

Wibowo, Y.D. (2010). Faktor-faktor yang Mempengaruhi Penerimaan Opini Audit Wajar Tanpa Pengecualian dengan Paragraph Penjelas: "Going Concern". Skripsi, Universitas Indonesia.

Wibowo, A., \& Rossieta H. (2009). Faktor-faktor Determinasi Kualitas Audit: Suatu Studi dengan Pendekatan Earnings Surprise Benchmark. Simposium Nasional Akuntansi XII.

Yunior, W.S. (2009). Pengaruh Kualitas Akrual Sebagai Risiko Informasi Terhadap Biaya Modal Perusahaan: Studi Empiris Perusahaan Publik yang Terdaftar di Bursa Efek Indonesia Tahun 2007. Skripsi, Universitas Indonesia. 